\title{
The Information System Model in Combating the Pandemic of Coronavirus (Covid-19) Environment: The Case of Mysejahtera
}

\author{
Rusli Abdullah, Yousef A. M. Qasem
}

To Link this Article: http://dx.doi.org/10.6007/IJARBSS/v11-i19/11734

DOI:10.6007/IJARBSS/v11-i19/11734

Received: 04 October 2021, Revised: 06 November 2021, Accepted: 29 November 2021

Published Online: 14 December 2021

In-Text Citation: (Abdullah \& Qasem, 2021)

To Cite this Article: Abdullah, R., \& Qasem, Y. A. M. (2021). The Information System Model in Combating the Pandemic of Coronavirus (Covid-19) Environment: The Case of Mysejahtera. International Journal of Academic Research in Business and Social Sciences, 11(19), 256-263.

Copyright: (c) 2021 The Author(s)

Published by Human Resource Management Academic Research Society (www.hrmars.com) This article is published under the Creative Commons Attribution (CC BY 4.0) license. Anyone may reproduce, distribute, translate and create derivative works of this article (for both commercial and non-commercial purposes), subject to full attribution to the original publication and authors. The full terms of this license may be seen at: http://creativecommons.org/licences/by/4.0/legalcode

Special Issue Title: Youth and Community Wellness, 2021, Pg. 256 - 263

Full Terms \& Conditions of access and use can be found at http://hrmars.com/index.php/pages/detail/publication-ethics 


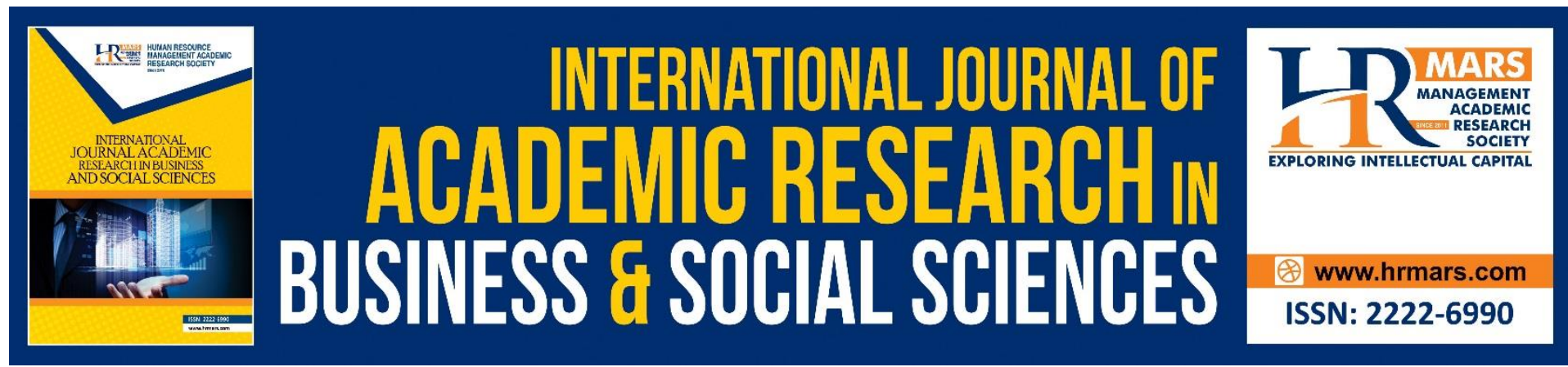

\title{
The Information System Model in Combating the Pandemic of Coronavirus (Covid-19) Environment: The Case of Mysejahtera
}

\author{
Rusli Abdullah", 1, a , Yousef A. M. Qasem ${ }^{1, b}$ \\ ${ }^{1}$ Institute for Social Science Studies, Putra Infoport, Universiti Putra Malaysia, 43400 \\ Serdang, Selangor, Malaysia, ${ }^{2}$ Faculty of Computer Science and Information Technology, \\ Universiti Putra Malaysia, 43400 Serdang, Selangor, Malaysia \\ Email: rusli@upm.edu.my ${ }^{\mathrm{a}}$,gs45505@student.upm.edu.my ${ }^{\mathrm{b}}$
}

\section{Abstract}

The role of Information systems (IS) in our life is so commons and it is also required to be used anywhere, on any platforms, and anytime nowadays especially in relation to combating the pandemic of coronavirus (Covid-19) to sustain the quality of our life. The COVID-19 pandemic has put health systems, economies and societies under unprecedented situation, calling for innovative approaches. Governments have intensively depended on IS to promote public health. During the COVID-19 pandemic, "contact tracing apps" for smartphones have also been promoted in many countries as a way to allow officials to facilitate contact tracing. In line with our discussion and research work purposes in this article, we take into consideration the application that is introduced by the Ministry of Health (MoH) called MySejahtera. The system has several functionalities which are starting from user registration, identify the hotspot Covid-19, check-in into selected premises in controlling contact tracing of the Covid19. However, the functionalities are quite very subjective. Therefore, this paper is developed in order to propose a comprehensive model of IS and its functionalities in combating the pandemic of coronavirus (covid-19) environment. To achieve this purpose, a review and analysis of the literature based on their importance in related IS and its functionality has been performed. Furthermore, using this IS model in relation to combat the Covid-19, the citizen or anyone who used or applied this IS can always be aware of the importance based on its functionalities comprehensively and significantly.

Keywords: Information System, MySejahtera Application, Citizen, Ministry of Health, Quality of Life

\section{Introduction}

Coronavirus disease (COVID-19) is an infectious disease caused by the SARS-CoV-2 virus. Globally, as of 26 October 2021, there have been 243,857,028 confirmed cases of COVID-19, including 4,953,246 deaths, reported to WHO. As of 25 October 2021, a total of 6,697,607,393 vaccine doses have been administered. The role of Information Systems (IS) in our life is so commons and it is also required to be used anywhere, on any platforms, and anytime nowadays especially concerning combating the pandemic of coronavirus (Covid-19) to sustain 
the quality of our life. The COVID-19 pandemic has put health systems, economies and societies under unprecedented situation, calling for innovative approaches. Governments have intensively depended on IS to promote public health. During the COVID-19 pandemic, "contact tracing apps" for smartphones have also been promoted in many countries as a way to allow officials to facilitate contact tracing.

In line with our discussion and research work purposes in this article, we take into consideration of the application that is introduced by the Ministry of Health (MoH) of IS in helping the citizens called MySejahtera. The system has several functionalities which are starting from user registration, identify the hotspot Covid-19, check-in into selected premises in controlling contact tracing of the Covid-19. However, the functionalities are quite very subjective.

Therefore, this paper is developed to propose a comprehensive model of IS and its functionalities in combating the pandemic of coronavirus (covid-19) environment. Furthermore, by using this IS model concerning combating the Covid-19, so that the citizen or anyone who are used or applied this IS can always be aware of the importance based on its functionalities comprehensively and significantly. In this paper, we will present the literature review in Section 2, the research methodology in Section 3, and Result and Discussion in section 4 , and ending by the Conclusion section.

\section{Literature Review}

With the development of various technologies that can be applied to tackle major problems and diseases, there are many researchers have examined those technologies for monitoring, surveillance, detection, and prevention of COVID-19 (Jankovic et al., 2020; O'Leary, 2020, Pan and Zhang, 2020; Abdullah et al., 2020; Carin et al., 2020; Zhang, 2020, He, Zhang et al., 2021; Edwards et al., 2021; Abdullah et al., 2021; Krapivin et al., 2021).

For the literature review (LR) in explaining the relationship of information system (IS) and its application to combat the pandemic Covid-19 environment, the conceptual definition of these terminologies will be discussed based on the components as starting as follows:

\section{What is Information Systems?}

Information or Application (App) System (Sys) or called as IS is a created or customized software that has been developed on top of a hardware platform to help everyone for specific purposes of their activities. This application software or in short called App Sys or IS is worked based on the following functionality:

- $\quad$ For learning or education either online or offline purposes is called e-learning

- $\quad$ For gaming or sport of online purposes is called as E-Games or e-Sport

- For entertainment to fulfill their leisure time of online is called as E-Entertainment

- $\quad$ For shopping of online purposes is called E-Shopping

- For managing and conducting the business of online business is called E-Business

- For managing and recording of healthcare of online purpose is called E-Health especially in related to Pandemic Covid-19 environment.

What is Pandemic of Coronavirus (Covid-19)?

Covid-19 is the Pandemics that are working together to achieve their missions of the business for future development environment based on a specific purpose.

\section{MySejahtera and Its Functionalities to Combat the Pandemic Covid-19 Environment}


In a country like Malaysia, MySejahtera was introduced by the Ministry of Health (MoH) that has several functionalities. These are including;

- User registration,

- Identify the hotspot Covid-19,

- $\quad$ check-in to selected premises in controlling contact tracing of the Covid-19.

Similar Information Systems Used in Southeast Asia Countries for Pandemic Purposes In other countries of Southeast Asia as stated in Table 1 also have the same features or functionalities which are having a specific or unique name in helping their citizen and noncitizenship.

Table 1: The countries and it's IS application to combat Pandemic Covid-19

\begin{tabular}{ccc}
\hline Number & Country & Name of Application \\
\hline 1 & Singapore & TraceTogether \\
2 & Indonesia & PeduliLindungi \\
3 & Thailand & ThailandPlus \\
4 & Brunei & BruHealth \\
5 & Philippines & StaySafe \\
\hline
\end{tabular}

\section{Research Methodology}

In order to develop a proposed model of IS in combating the pandemic Covid-19, a review of the literature based on their importance in related IS and its functionality has been performed in this area of research. These are including getting data from secondary platforms which are in the forms of softcopy and hard copy especially in the internet kinds of information or knowledge as well as other related issues and their challenges throughout documentation explicitly (Fazel Ansari, 2019). And then, the data has been gathered and analyzed accordingly. Furthermore, it has been categorized based on the related system application or utilization together with their related business purposes based on issues and challenges that are needed to be faced by the citizen for their current requirement or use, and for the future.

\section{A Proposed Model of Information System Model to Combat Pandemic of Covid-19}

Based on the LR that has been done, the proposed model of IS for combating pandemic Covid19 is developed which is related to the macro-level of the system functionalities that can be categorized into several systems. The IS model and its macro level of system and its functionalities to combat Pandemic Covid-19 are shown in Figure 1. 


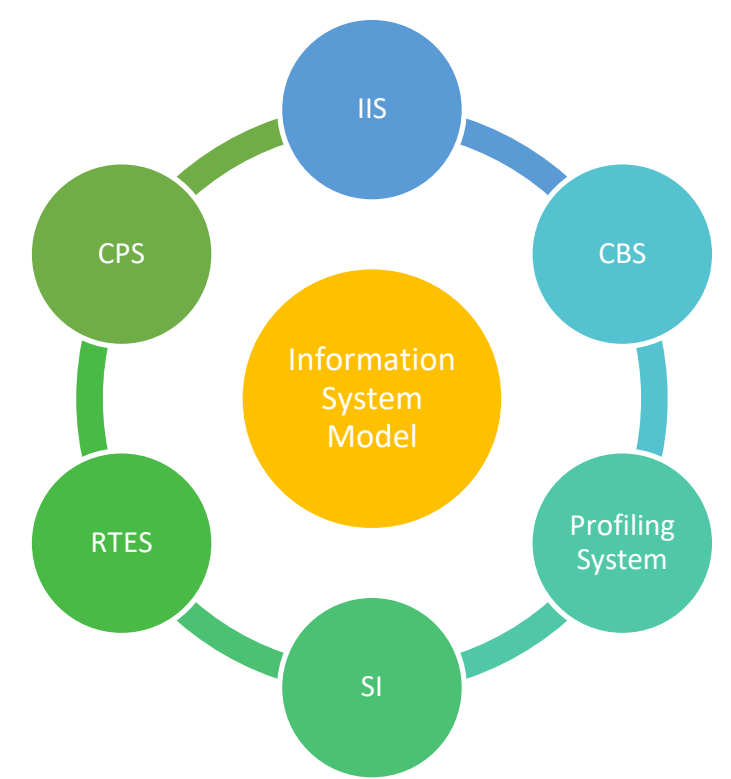

Figure 1: A proposed model of Information System at macro level to combat Pandemic Covid-19

The beauty of these applications as a system model is that they can be promoted the connection process as well as work collaboratively especially in using industrial revolution IR4.0 application in servicing the business for its survivalist and sustainability. These are something that required by a citizen in real life that is developed as follows:

\section{Profiling System (PS)}

This is the application system that is used by the citizen to register them into the system and they also can help them to monitor something regarding on the pandemic of the Covid-19 environment.

\section{Intelligent Information System (IIS)}

This is a feature that needs to be done or design in the system by using agent technology. These agents are working in the context of push and pull technology especially in reminding and alerting the users about something that needed to be done and to be aware of something autonomously. The system also needs to strengthen the profiling system, so that it will be working more comprehensively and significantly.

\section{Realtime Time Embedded System (RTES)}

This is a Real-Time and Embedded System that can be developed to ensure the system can trigger something by informing the user about hotspots and cold spots in assisting the users to help them to monitor the current state or status of something happening in their area of business. The system also may be used or connect to another system and work automatically. For example, to monitor healthcare and many others especially in relation to social distancing purposes.

\section{System Integration (SI)}

This is a system that will be linked from MySejahtera System to another system in allowing the community of practice to monitor each other. Besides that, the system also can be used to help everyone to perform their business in relation to Covid-19 purposes. 


\section{Cyber Physical System (CPS)}

This is a system to allow everyone to be connected to the cyberworld by using their devices such as CCTV, laptop, and Personal Computer (PC) in helping them to monitor and to control as well as to get information about everything related to Covid-19 around the world environment. The system also can help everyone to monitor the numbers of the community of users in a particular event automatically in a physical location or remotely.

Cloud Based System (CBS)

This is about system networking that allows everyone to be connected in a particular area or region locally and globally.

\section{Result and Discussion}

In the context of the system model for citizenship activities, the main component that is needed to be considered is related to the micro -level of system functionalities. These components are divided into three aspects of issues and their challenges to ensure they can shape future purposes as shown in Figure 2.

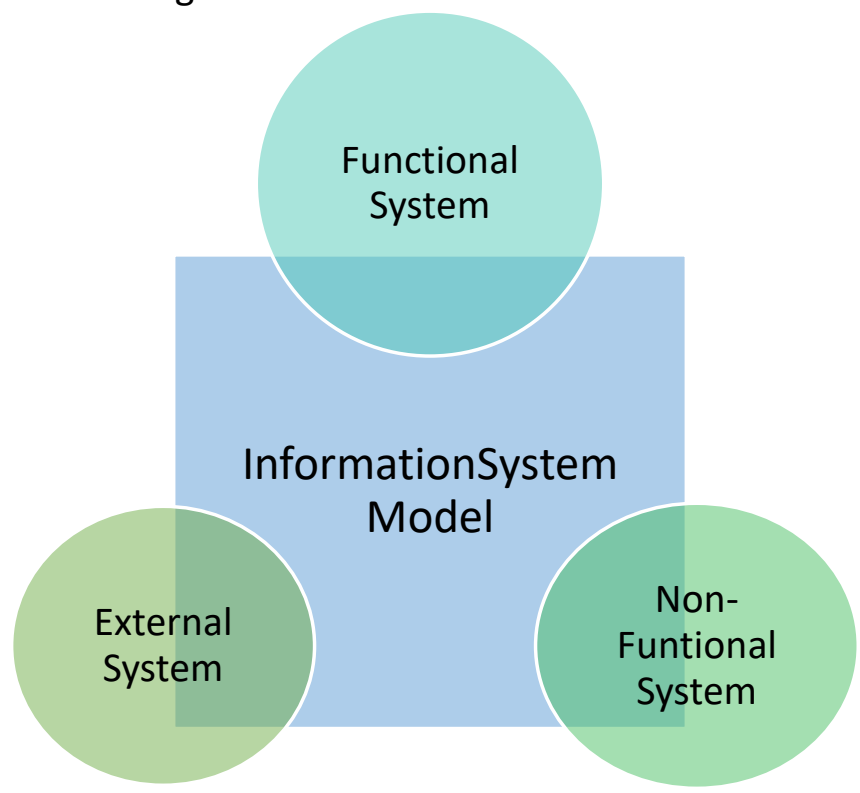

Figure 2. The three mains aspect of Issues and Challenges

These are categorized into three aspects that are including as follow:

Functional Requirement.

The technical aspect is related to the issues on how to operate and sometimes is also involved a little bit of coding to ensure that the hardware and software can have connected each other for its functions or processes specifically.

- Capture Information is the most important part as a device or tool that needs to be understood by the citizen on how to use or operation for specific functionality.

- Storing is another issue that is needed to be understood by citizens especially with regards to the operating system (OS) as a platform to run or implement the additional software or package-like application system based on its specific functionality.

- Reporting is a very important aspect that is required by the citizen to get the enjoyment of application system which is available for them to monitor the pandemic personally. 


\section{Non-Functional Requirement}

The non-functional requirement aspect is related to the issues on how to ensure that the operation can be done smoothly with the effectiveness and its efficiency as well as ethically.

- The motivation issue is a social aspect that is needed to ensure that citizens can use the application system continuously. This is also to ensure that the citizens use apps sys all the time and it is normally to encourage them to utilize the technology for any purposes of their life. So that, they will happy and promote these kinds of technologies among them of their peers and they also can be as a promoter to use the business electronically and at the same time to increase their quality of life specifically.

- This is a very important aspect of the socialization process that is related to use the application systems ethically. Suppose the user needs to be honored in using the application system based on their awareness which is either can or cannot of doing something. Therefore, we can promote the ecosystem environment on the kind of application system with trustworthiness and safety. In another word, we are trying to promote the concept of respectability and integrity.

\section{External System}

The hybrid aspect is related to the issue of how to ensure that the technical aspect and social aspect can be worked together integrity and safely especially with regards to open-source software integration. Meaning that how to ensure the operation based on a specific function can be monitored and working securely and respectfully. The Security issue is given the main concerns in the application system with IR4.0 for citizenship activities to use it especially in ensuring that they are using the right product and at right time securely. This is also will ensure that everyone is under control and realizable of using the application systems as products or services securely and trustworthy.

\section{Conclusion}

There are a lot of advantage that can be gained by a citizen in using the IS application especially in combating the Pandemic Covid-19. And of course, there is a need of a citizen to be aware and concerned about the issues and challenges as critical success factors that are becoming the main part of the application system that can be used or implemented successfully. By understanding this scenario, members of citizens will maintain or sustain the benefits of using the application system for their future development survival as well as to maintain the quality of life. The current papers proposed a comprehensive model of IS and its functionalities in combating the pandemic of coronavirus (covid-19) environment. Testing and applying this model in order to enhance the efficiency and effectiveness of the tacking health systems such as MySejahtera is recommended.

\section{References}

Ansari, F. (2019). Knowledge management 4.0: theoretical and practical considerations in cyber physical production systems. IFAC-PapersOnLine, 52(13), 1597-1602.

Baygin, M., Yetis, H., Karakose, M., \& Akin, E. (2016). An effect analysis of industry 4.0 to higher education. In 2016 15th international conference on information technology based higher education and training (ITHET) (pp. 1-4). IEEE.

BruHealth. Brunei. http://www.moh.gov.bn/SitePages/bruhealth.aspx 
He, W., Zhang, Z. J., \& Li, W. (2021). Information technology solutions, challenges, and suggestions for tackling the COVID-19 pandemic. International journal of information management, 57, 102287.

Lockey, S., Edwards, M. R., Hornsey, M. J., Gillespie, N., Akhlaghpour, S., \& Colville, S. (2021). Profiling adopters (and non-adopters) of a contact tracing mobile application: insights from Australia. International Journal of Medical Informatics, 149, 104414.

Milenkovic, A., Jankovic, D., \& Rajkovic, P. (2020). Extensions and adaptations of existing medical information system in order to reduce social contacts during COVID-19 pandemic. International journal of medical informatics, 141, 104224.

MySejahtera. Malaysia. https://mysejahtera.malaysia.gov.my/

O'Leary, D. E. (2020). Evolving information systems and technology research issues for COVID19 and other pandemics. Journal of Organizational Computing and Electronic Commerce, 30(1), 1-8.

Pan, S. L., \& Zhang, S. (2020). From fighting COVID-19 pandemic to tackling sustainable development goals: An opportunity for responsible information systems research. International Journal of Information Management, 55, 102196.

Peduli Lindungi. Indonesia. https://pedulilindungi.id/

Peter, F. (2020). "Education 4.0 ... the future of learning will be dramatically different, in school and throughout life." https://www.thegeniusworks.com/2017/01/futureeducation-young-everyo ne-taught-together/

Price, W. H. (2014). "Industry 4.0 - Opportunities and Challenges of the Industrial Internet" https://www.pwc.nl/en/assets/documents/pwc-industrie-4-0.pdf.

Qasem, Y. A., Abdullah, R., Jusoh, Y. Y., Atan, R., \& Asadi, S. (2021). Analyzing Continuance of Cloud Computing in Higher Education Institutions: Should We Stay, or Should We Go?. Sustainability, 13(9), 4664.

Qasem, Y. A., Abdullah, R., Yaha, Y., \& Atana, R. (2020). Continuance use of cloud computing in higher education institutions: A conceptual model. Applied Sciences, 10(19), 6628.

Thailand Plus. Thailand. https://thailandplus.in.th/en/

Ting, D. S. W., Carin, L., Dzau, V., \& Wong, T. Y. (2020). Digital technology and COVID19. Nature medicine, 26(4), 459-461.

Trace Together, safer together. Singapore. https://www.tracetogether.gov.sg/ StaySafe.ph. Philippine. https://www.staysafe.ph/

Varotsos, C. A., Krapivin, V. F., Xue, Y., Soldatov, V., \& Voronova, T. (2021). COVID-19 Pandemic Decision Support System for an Appropriate Population Defense Strategy and Vaccination Effectiveness. Safety Science, 105370.

Zhang, T. (2020). Integrating geographic information system technique with Google Trends data to analyse COVID-19 severity and public interest. Public Health, 189, 3. 